Jurnal Keperawatan Silampari

Volume 2, Nomor 2, Juni 2019

e-ISSN: 2581-1975

p-ISSN: 2597-7482

DOI: https://doi.org/10.31539/jks.v2i2.505

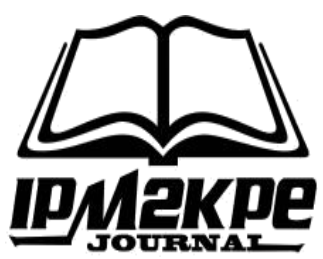

\title{
PENYEMBUHAN PRANIC HEALING TERHADAP KESEHATAN TUBUH FISIK PRIMIGRAVIDA TRIMESTER III
}

\author{
Cahyaning Puji Astuti ${ }^{1}$, Melyana Nurul Widyawati ${ }^{2}$ \\ Program Kebidanan Sains Terapan Pascasarjana, Poltekkes Kemenkes Semarang ${ }^{1,2}$ \\ astuticahyaning@gmail.com ${ }^{1}$
}

\begin{abstract}
ABSTRAK
Penelitian ini bertujuan untuk meningkatkan kondisi kesehatan tubuh fisik ibu hamil primigravida trimester ketiga. Metode dalam penelitian ini menggunakan randomized controlled trial design. Jenis penelitian menggunakan pre test \& post test group design. Hasil penelitian ini menunjukkan bahwa hasil energi organ sebagai indikator kesehatan tubuh fisik telah meningkatkan frekuensi pre dan post test. Tes ANOVA berulang menunjukkan penurunan pada kedua kelompok. Sedangkan hasil uji Wilcoxon menunjukkan bahwa terdapat perbedaan post test 2 organ energi $p=0,013(<0,05)$, post test 3 nilai $\mathrm{p} 0,001(<0,05)$. Simpulan, terapi penyembuhan prana dapat meningkatkan energi fisik ibu hamil.
\end{abstract}

Kata Kunci: Energi Organ, Kehamilan Trimester III, Penyembuhan Prana, Primigravida

\section{ABSTRACT}

This study aims to improve the physical health condition of third trimester primigravida pregnant women. The method in this study uses a randomized controlled trial design. This type of research uses pre-test \& post-test group design. The results of this study indicate that the results of organ energy as an indicator of physical body health have increased the frequency of pre and post test. The repeated ANOVA test showed a decrease in both groups. While the Wilcoxon test results showed that there were differences in the post test 2 energy organs $p=0.013(<0.05)$, post test $3 p$ value 0.001 (<0.05). Conclusion, pranic healing therapy can increase the physical energy of pregnant women.

Keywords: Organ Energy, Trimester III Pregnancy, Pranic Healing, Primigravida

\section{PENDAHULUAN}

Kehamilan adalah proses alami pada wanita dimana sel telur bertemu dengan sperma dan menjadi janin, secara umum proses kehamilan terjadi selama 38 - 40 minggu. Menurut Permenkes (2016) Proses kehamilan melibatkan beragam aktivitas tubuh, sehingga perubahan yang terjadi pada masa kehamilan mampu merubah mekanisme dan fungsi hormonal tubuh yang dapat menyebabkan terjadinya perubahan energi tubuh yang mempengaruhi kesehatan tubuh fisik dalam masa kehamilan yang akan berdampak pada proses persalinan. Berbagai permasalahan pada masa hamil berdampak buruk bukan saja pada ibu tetapi juga kepada bayi dalam kandungan. Oleh karenanya, kesehatan tubuh fisik yang optimal mampu menunjang keberlanjutan proses kehamilan dan persalinan yang berkualitas. Namun sayangnya permasalahan kesehatan 
tubuh fisik pada kehamilan belum terdeteksi khususnya di trimester III sebelum persalinan yang merupakan periode akumulasi dari beragam keluhan (Sui MCK, 2010).

Kesehatan tubuh fisik yang terganggu dapat menyebabkan depresi dan kecemasan pada wanita selama masa kehamilan, dari 348 wanita hamil trimester III yang melakukan antenatal care rutin, didapatkan $21,7 \%$ ibu hamil mengalami depresi berat, $15,7 \%$ mengalami kecemasan tingkat tinggi dan $12,5 \%$ memiliki kecemasan traumatis tinggi. Hal ini harus mendapatkan perhatian dan penatalaksanaan agar tidak terjadi masalah psikologis yang berlanjut hingga post partum (Podvornik $\mathrm{N}$ et al, 2015).

Wanita yang baru pertama kali mengalami kehamilan disebut primigravida, hampir semua primigravida mengalami kecemasan, ketakutan dan kekhawatiran baik selama masa kehamilan, menjelang proses persalinan hingga selesai proses persalinan. Kecemasan yang timbul disebabkan oleh belum siapnya diri ibu hamil atas perubahan fisik, timbul ketidaknyamanan dalam kehamilan seperti mual muntah, nyeri punggung dan lainnya, sehingga kecemasan tersebut menimbulkan efek psikologis yang kurang baik bagi ibu hamil dan janin dalam kandungan (Bethsaida, 2010).

Manusia memiliki tubuh fisik dan tubuh energi, kesehatan tubuh energi dan kesehatan tubuh fisik saling berhubungan dan terkait satu dengan yang lain, apabila tubuh energi terganggu maka tubuh fisik dan psikologis akan terganggu (Sui MCK, 2010; Sui MCK, 2009; Sui MCK, 2010; Sui MCK, 2012). Pada umumnya pengobatan pada ibu hamil menggunakan pengobatan farmakologis dimana terdapat efek samping yang timbul dari obat, pranic healing merupakan salah satu pengobatan holistik yang bersifat non farmakologis dapat menggurangi penggunaan obat farmakologis (Rajagopal, Jois, Mallikarjuna, Anil K, \& Shashidhar, 2017).

Terapi penyembuhan pranic healing merupakan terapi penyembuhan kuno yang berfokus pada penyembuhan pada medan energi di sekitar dan di dalam tubuh manusia. Terapi penyembuhan ini merupakan terapi pelengkap dengan memanfaatkan prana atau energi tanpa sentuhan sebagai sumber utama penyembuhan. Sama halnya dengan tubuh fisik seperti organ tubuh vital dan minor, tubuh energi juga memiliki cakra minor, cakra mayor dan aura. Oleh karena itu, tubuh energi dan tubuh fisik memiliki keterkaitan yang saling menguatkan antara satu dengan yang lainnya (Sui MCK, 2010; Sui MCK 2012). Dalam penelitian ini, dilakukan penelusuran kualitas kesehatan tubuh fisik ibu primigravida melalui deteksi energi prana dan melakukan penerapan terapi pranic healing dalam upaya menstabilkan energi dalam tubuh energi yang secara langsung mempengaruhi kualitas kesehatan tubuh fisik.

\section{METODE PENELITIAN}

Penelitian ini merupakan penelitian true eksperimental dengan desain randomized controlled trials (RCTs). Penelitian dilaksanakan di Klinik Ngesti Widodo Ungaran Indonesia. Penelitian ini dibagi menjadi 2 kelompok yaitu kelompok intervensi dan kelompok kontrol. Kelompok intervensi adalah ibu hamil primigravida trimester III dengan terapi penyembuhan intervensi pranic healing dan pada kelompok kontrol adalah ibu hamil primigravida trimester III yang mendapatkan perawatan dan pengobatan standar umum untuk ibu hamil sesuai kehamilannya.

Jumlah populasi ibu hamil dalam penelitian ini berjumlah 164 orang. Terdapat responden yang termasuk dalam kriteria eksklusi sebanyak 114 responden dan terdapat 8 responden yang mengalami drop out. Sehingga jumlah responden penelitian iniberjumlah 42 responden pada kedua kelompok baik kelompok kontrol maupun 
kelompok intervensi yang telah dilakukan terapi penyembuhan terapi pranic healing dan asuhan standar kebidanan.

Penelitian ini menerapkan teknik penanganan pranic healing terhadap kesehatan fisik pada ibu hamil primigravida trimester III. Terapi penyembuhan pranic healing telah dilakukan satu kali seminggu dengan durasi 30 menit selama 3 minggu dan pengukuran satu kali dalam seminggu selama 4 minggu. Analisa penelitian dilakukan dengan membandingkan hasil antara pre test dan post test 1, post test 2, dan post test 3. Penelitian ini dilakukan time series analysis karena dalam penelitian ini melakukan pengukuran yang berulang sebanyak 4 kali pada kelompok intervensi dan kelompok kontrol.

\section{HASIL PENELITIAN}

Tabel. 1

Distribusi Frekuensi Karakteristik Responden Analisa Univariat

\begin{tabular}{|c|c|c|c|c|c|}
\hline \multirow{3}{*}{ No } & \multirow{3}{*}{ Karakteristik Variabel } & \multicolumn{4}{|c|}{ Kelompok Penelitian } \\
\hline & & \multicolumn{2}{|c|}{ Kontrol } & \multicolumn{2}{|c|}{ Pranic Healing } \\
\hline & & Frekuensi & $\%$ & Frekuensi & $\%$ \\
\hline \multirow[t]{6}{*}{1.} & $\begin{array}{l}\text { Klasifikasi } \\
\text { (tahun) }\end{array}$ & & & & \\
\hline & a. $<19$ Tahun & - & - & - & - \\
\hline & b. 20-30 Tahun & 13 & 92,9 & 12 & 85,7 \\
\hline & c. 31-40 Tahun & 1 & 7,1 & 2 & 14,3 \\
\hline & d. > 40 Tahun & - & - & - & - \\
\hline & Jumlah & 14 & 100 & 14 & 100 \\
\hline \multirow[t]{6}{*}{2.} & Jenis Pekerjaan & & & & \\
\hline & a. Ibu Rumah Tangga & 4 & 28,6 & 3 & 21,4 \\
\hline & b. Wiraswasta & 1 & 7,1 & 2 & 14,3 \\
\hline & c. Karyawan Swasta & 8 & 57,1 & 6 & 42,9 \\
\hline & $\begin{array}{l}\text { d. Pegawai Negeri } \\
\text { Sipil }\end{array}$ & 1 & 7,1 & 3 & 21,4 \\
\hline & Jumlah & 14 & 100 & 14 & 100 \\
\hline \multirow[t]{4}{*}{3.} & $\begin{array}{l}\text { Umur Kehamilan } \\
\text { a. 28-32 Minggu }\end{array}$ & 12 & 85,7 & 7 & 50 \\
\hline & b. 33-36 Minggu & 2 & 14,3 & 6 & 42,9 \\
\hline & c. $>36$ minggu & - & - & 1 & 7,1 \\
\hline & Jumlah & 14 & 100 & 14 & 100 \\
\hline
\end{tabular}

Berdasarkan tabel 1 hasil penelitian dapat diinterpretasikan bahwa dari karakteristik umur, rentang umur terbanyak secara statistik berada pada usia ideal reproduksi yakni berumur 20-30 tahun sejumlah 13 orang (92.9\%). Karakteristik pekerjaan, sebagian besar responden bekerja sebagai karyawan swasta sejumlah 8 orang (57.1\%). Karakteristik usia kehamilan, usia 28-32 minggu memiliki kecenderungan lebih tinggi dibandingkan lainnya sejumlah 12 orang $(85.7 \%)$.

Kesehatan tubuh fisik secara langsung dipengaruhi oleh aura, cakra mayor dan cakra minor. Melalui terapi pranic healing mampu mengintegrasikan mekanisme tubuh dalam merawat kesehatan tubuh fisik dan tubuh energi. Penilaian intervensi terfokus pada penanganan masalah kesehatan umum kehamilan di trimester II yang meliputi masalah tubuh fisik seperti kontraksi braxton hicks, nyeri ulu hati, nyeri punggung, hidung tersumbat dan mimisan.

Kondisi fisik responden dalam penelitian ini dapat dijelaskan bahwa kondisi kurang sehat pada bagian organ sacrum, rahang gigi, liver, ginjal, kelenjar air susu, 
sistem pernafasan dan limpa. Hasil pengukuran menunjukkan bahwa kondisi salah satu responden kelompok kontrol pre test dapat disajikan pada gambar 1. Sedangkan hasil pengukuran kondisi salah satu responden kelompok intervensi pre test disajikan pada gambar 2 .

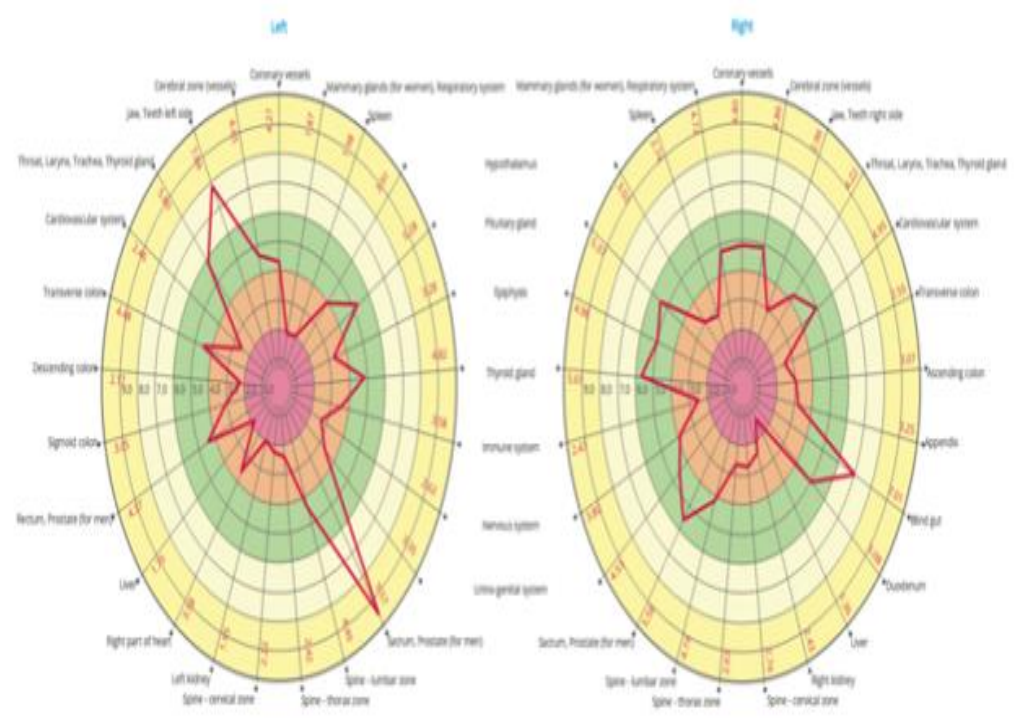

: energy reserve organs

Gambar. 1

Pre test kondisi kesehatan fisik responden kelompok kontrol

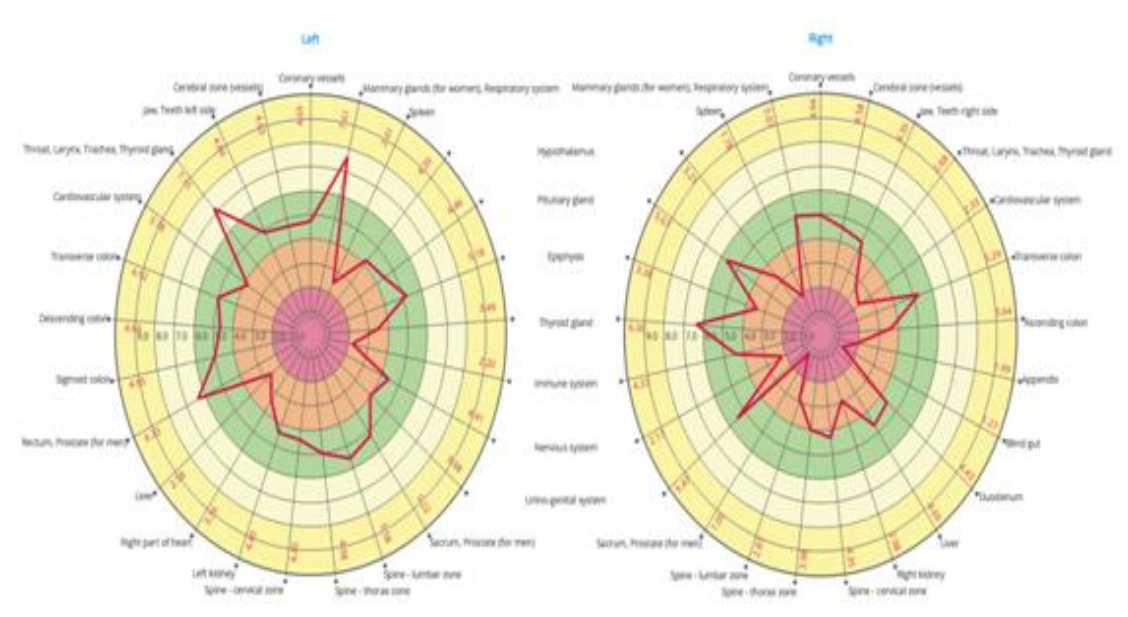

: energy reserve organs

Gambar. 2

Pre test kondisi kesehatan fisik responden kelompok intervensi 
Hasil pengukuran keluhan kesehatan fisik responden pada kelompok kontrol dan kelompok intervensi dari seluruh responden dapat disajikan secara berurutan pada tabel 2 dan tabel 3 sebagai berikut.

Tabel. 2

Hasil Pengukuran Keluhan Kesehatan Fisik Responden pada Kelompok Kontrol

\begin{tabular}{|c|c|}
\hline Responden & Keluhan pada organ \\
\hline A1 & Tidak mempunyai keluhan secara fisik pada organ dan sistem tubuh \\
\hline A2 & $\begin{array}{l}\text { Terdapat keluhan fisik seperti liver, ginjal kiri dan kanan, saluran pencernaan } \\
\text { (blind gut), tulang panggul (sacrum), kelenjar air susu (mammary gland), sistem } \\
\text { pernafasan }\end{array}$ \\
\hline A3 & Tidak mempunyai keluhan secara fisik pada organ dan sistem tubuh \\
\hline A4 & $\begin{array}{l}\text { Terdapat keluhan pada permasalahan fisik, organ yang mempunyai keluhan } \\
\text { adalah sacrum, kelenjar tiroid dan kelenjar pituitary }\end{array}$ \\
\hline A6 & Terdapat keluhan pada organ rektum, tenggorok, kelenjar tiroid dan ginjal kiri \\
\hline A7 & $\begin{array}{l}\text { Terdapat keluhan pada organ kiri rektum, kelenjar air susu (mammary gland), } \\
\text { dan kurang sehat pada sistem pernafasan dan sistem syaraf }\end{array}$ \\
\hline A8 & $\begin{array}{l}\text { Secara umum kondisi fisik responden baik, namun ada beberapa organ yang } \\
\text { perlu diperhatikan kesehatannya yaitu, liver, area rahang dan gigi }\end{array}$ \\
\hline A9 & $\begin{array}{l}\text { Kondisi fisik responden kurang baik karena beberapa organ mengalami } \\
\text { gangguan, organ yang mengalami gangguan adalah liver, organ limpa, tulang } \\
\text { belakang dekat area pernafasan hipotalamus, rahang dan gigi, sistem kekebalan } \\
\text { tubuh }\end{array}$ \\
\hline A11 & $\begin{array}{l}\text { Kondisi fisik pada responden terdapat organ yang perlu diperhatikan yaitu organ } \\
\text { liver dan organ pembuluh darah otak }\end{array}$ \\
\hline A12 & $\begin{array}{l}\text { Kondisi fisik responden terdapat permasalahan pada bagian kiri terdapat } \\
\text { masalah di rektum, liver, usus besar, bagian usus besar yang menghubungkan } \\
\text { dengan rektum }\end{array}$ \\
\hline A15 & $\begin{array}{l}\text { Kondisi fisik responden terdapat permasalahan akibat kelelahan fisik, } \\
\text { iritabilitas, organ yang terganggu yaitu usus besar menurun, usus sigmoid, } \\
\text { rektum, usus buntu, rahang krir, gigi, hypotalamus }\end{array}$ \\
\hline A16 & Tampak kondisi fisik responden A16 secara umum baik \\
\hline A17 & Tampak kondisi fisik responden A16 secara umum baik \\
\hline A18 & $\begin{array}{l}\text { Kondisi fisik responden terdapat permasalahan akibat kurang sehat, terlihat pada } \\
\text { organ bagian kiri yaitu norgan sakrum, pada rahang, gigi, liver, ginjal, kelenjar } \\
\text { air susu, sistem pernafasan, limpa, pada bagian kanan organ liver juga } \\
\text { bermasalah }\end{array}$ \\
\hline
\end{tabular}

Tabel. 3

Hasil Pengukuran Keluhan Kesehatan Fisik Responden pada Kelompok Intervensi

\begin{tabular}{cl}
\hline Responden & \multicolumn{1}{c}{ Keluhan pada Organ } \\
\hline B1 & $\begin{array}{l}\text { Terdapat keluhan secara fisik pada organ sakrum, limpa, sistem kekebalan } \\
\text { tubuh }\end{array}$ \\
B3 & $\begin{array}{l}\text { Terdapat keluhan pada beberapa organ yang mempunyai keluhan fisik, yaitu } \\
\text { tulang belakang di area paru-paru, area gigi dan rahang }\end{array}$ \\
B5 & $\begin{array}{l}\text { Tidak mempunyai keluhan secara fisik pada organ dan sistem tubuh } \\
\text { B6 }\end{array}$ \\
& $\begin{array}{l}\text { Terdapat keluhan pada beberapa organ mengalami permasalahan fisik, yaitu } \\
\text { sakrum, usus buntu, limpa, kelenjar air susu }\end{array}$ \\
B7 & $\begin{array}{l}\text { Kondisi fisik responden terdapat keluhan pada organ sakrum, rahang, gigi } \\
\text { kurang sehat } \\
\text { Terdapat permasalahan pada ginjal kanan kondisi lemah, sistem syaraf }\end{array}$ \\
B8 & $\begin{array}{l}\text { Secara umum kondisi fisik responden dalam keadaan baik, namun ada } \\
\text { beberapa organ yang perlu diperhatikan kesehatannya, yaitu limpa, tulang } \\
\text { epifis } \\
\text { Kondisi fisik responden kurang baik karena beberapa organ mengalami }\end{array}$ \\
\end{tabular}




\begin{tabular}{cl}
\hline & $\begin{array}{l}\text { gangguan, organ yang mengalami masalah adalah sakrum, rahang dan gigi } \\
\text { sebelah kiri } \\
\text { K11 }\end{array}$ \\
Kondisi fisik pada responden baik terdapat organ yang perlu diperhatikan \\
yaitu kelenjar air susu, sistem syaraf \\
Kondisi fisik responden terdapat permasalahan pada beberapa organ kurang \\
sehat yaitu rektum, sakrum, usus buntu, rahang dan gigi \\
K13 & $\begin{array}{l}\text { Kondisi fisik responden dalam kondisi kurang sehat terlihat pada organ } \\
\text { rahang dan gigi, sistem syaraf, sistem kekebalan tubuh, organ limpa }\end{array}$ \\
B14 & $\begin{array}{l}\text { Kondisi fisik responden kurang baik pada organ rektum, sakrum, sistem urine, } \\
\text { kelenjar air susu, liver, tenggorok, kelenjar tiroid } \\
\text { Kondisi fisik responden secara umum kelelahan, ada beberapa bagian dengan } \\
\text { kondisi fisik kurang sehat seperti servik, paru-paru } \\
\text { Kondisi fisik responden kurang sehat, terlihat pada organ bagian kiri yaitu } \\
\text { organ rektum dan liver yang lemah }\end{array}$ \\
\hline
\end{tabular}

Tabel. 4

Hasil Pengukuran Pre Test dan Post Test Keluhan Kesehatan Fisik Responden pada Kelompok Kontrol

\begin{tabular}{|c|c|c|}
\hline Responden & Pre Test & Post Test 3 \\
\hline A1 & $\begin{array}{l}\text { Tidak mempunyai keluhan secara fisik } \\
\text { pada organ dan sistem tubuh }\end{array}$ & Kelelahan fisik \\
\hline $\mathrm{A} 2$ & $\begin{array}{l}\text { Terdapat keluhan fisik seperti liver, } \\
\text { ginjal kiri dan kanan, saluran pencernaan } \\
\text { (blind gut), tulang panggul (sacrum), } \\
\text { kelenjar air susu (mammary gland), } \\
\text { sistem pernafasan }\end{array}$ & $\begin{array}{l}\text { Kelelahan fisik, hypotalamus, tulang } \\
\text { belakang }\end{array}$ \\
\hline A3 & $\begin{array}{l}\text { Tidak mempunyai keluhan secara fisik } \\
\text { pada organ dan sistem tubuh }\end{array}$ & $\begin{array}{l}\text { Kelelahan fisik, tenggorok, kelenjar } \\
\text { tiroid }\end{array}$ \\
\hline A4 & $\begin{array}{l}\text { Sacrum, kelenjar tiroid dan kelenjar } \\
\text { pituitary }\end{array}$ & $\begin{array}{l}\text { Kelelahan fisik, liver, ginjal, ragang, } \\
\text { gigi }\end{array}$ \\
\hline A6 & $\begin{array}{l}\text { Terdapat keluhan pada organ rektum, } \\
\text { tenggorok, kelenjar tiroid dan ginjal kiri }\end{array}$ & $\begin{array}{l}\text { Area otak, liver, kelenjar air susu, } \\
\text { tulang belakang, jantung koroner }\end{array}$ \\
\hline A7 & $\begin{array}{l}\text { Terdapat keluhan pada organ kiri rektum, } \\
\text { kelenjar air susu (mammary gland), dan } \\
\text { kurang sehat pada sistem pernafasan dan } \\
\text { sistem syaraf }\end{array}$ & Limpa, liver, tenggorok \\
\hline A8 & Liver, area rahang dan gigi & $\begin{array}{l}\text { Kelelahan fisik, sakrum, saluran } \\
\text { kencing, tulang paha, sistem syaraf, } \\
\text { tenggorok }\end{array}$ \\
\hline A9 & $\begin{array}{l}\text { Organ liver, organ limpa, tulang } \\
\text { belakang dekat area pernafasan } \\
\text { hipotalamus, rahang dan gigi, sistem } \\
\text { kekebalan tubuh }\end{array}$ & $\begin{array}{l}\text { Kelelahan fisik, limpa, sistem syaraf, } \\
\text { tulang belakang, ginjal, hypotalamus }\end{array}$ \\
\hline A11 & $\begin{array}{l}\text { Organ liver dan organ pembuluh darah } \\
\text { otak }\end{array}$ & $\begin{array}{l}\text { Kelelahan fisik, sakrum, kelenjar } \\
\text { tiroid, liver, jantung koroner, limpa, } \\
\text { tenggorokan }\end{array}$ \\
\hline A12 & $\begin{array}{l}\text { Rektum, liver, usus besar, bagian usus } \\
\text { besar yang menghubungkan dengan } \\
\text { rektum }\end{array}$ & Liver, sakrum, gigi \\
\hline A15 & $\begin{array}{l}\text { Organ yang terganggu yaitu usus besar } \\
\text { menurun, usus sigmoid, rektum, usus } \\
\text { buntu, rahang krir, gigi, hypotalamus }\end{array}$ & $\begin{array}{l}\text { Kelelahan fisik, saluran kencing, } \\
\text { ginjal, jantung koroner, limpa, usus } \\
12 \text { jari, rahang dan gigi }\end{array}$ \\
\hline A16 & $\begin{array}{l}\text { Tampak kondisi fisik responden A16 } \\
\text { secara umum baik }\end{array}$ & Hypotalamus, limpa \\
\hline A17 & $\begin{array}{l}\text { Tampak kondisi fisik responden A16 } \\
\text { secara umum baik }\end{array}$ & $\begin{array}{l}\text { Liver, kelenjar tiroid, sistem syaraf, } \\
\text { limpa, liver, tulang belakang }\end{array}$ \\
\hline A18 & Organ bagian kiri yaitu norgan sakrum, & Liver, ginjal, sistem syaraf, rahang, \\
\hline
\end{tabular}




\begin{tabular}{|c|c|c|}
\hline & \multicolumn{2}{|l|}{$\begin{array}{l}\text { pada rahang, gigi, liver, ginjal, kelenjar } \\
\text { air susu, sistem pernafasan, limpa, pada } \\
\text { bagian kanan organ liver juga } \\
\text { bermasalah }\end{array}$} \\
\hline \multicolumn{3}{|c|}{$\begin{array}{c}\text { Tabel. } 5 \\
\text { Hasil Pengukuran Pre Test dan Post Test Keluhan Kesehatan Fisik Responden } \\
\text { pada Kelompok Intervensi }\end{array}$} \\
\hline Responden & Pre Test & Post Tes 3 \\
\hline B1 & $\begin{array}{l}\text { Terdapat keluhan secara fisik pada organ sakrum, limpa, } \\
\text { sistem kekebalan tubuh }\end{array}$ & Liver \\
\hline B3 & $\begin{array}{l}\text { Terdapat keluhan pada beberapa organ yang mempunyai } \\
\text { keluhan fisik, yaitu tulang belakang di area paru-paru, area } \\
\text { gigi dan rahang }\end{array}$ & $\begin{array}{l}\text { Jantung, sistem } \\
\text { kekebalan tubuh }\end{array}$ \\
\hline B5 & $\begin{array}{l}\text { Tidak mempunyai keluhan secara fisik pada organ dan } \\
\text { sistem tubuh }\end{array}$ & Limpa, sistem syaraf \\
\hline B6 & $\begin{array}{l}\text { Terdapat keluhan pada beberapa organ mengalami } \\
\text { permasalahan fisik, yaitu sakrum, usus buntu, limpa, } \\
\text { kelenjar air susu }\end{array}$ & Saluran kencing \\
\hline B7 & $\begin{array}{l}\text { Kondisi fisik responden terdapat keluhan pada organ } \\
\text { sakrum, rahang, gigi kurang sehat }\end{array}$ & Sakrum, liver \\
\hline B8 & $\begin{array}{l}\text { Terdapat permasalahan pada ginjal kanan kondisi lemah, } \\
\text { sistem syaraf }\end{array}$ & $\begin{array}{l}\text { Tulang belakang, } \\
\text { sistem kekebalan } \\
\text { tubuh }\end{array}$ \\
\hline B9 & $\begin{array}{l}\text { Secara umum kondisi fisik responden dalam keadaan baik, } \\
\text { namun ada beberapa organ yang perlu diperhatikan } \\
\text { kesehatannya, yaitu limpa, tulang epifis }\end{array}$ & Rahang \\
\hline B10 & $\begin{array}{l}\text { Kondisi fisik responden kurang baik karena beberapa } \\
\text { organ mengalami gangguan, organ yang mengalami } \\
\text { masalah adalah sakrum, rahang dan gigi sebelah kiri }\end{array}$ & Tenggorok \\
\hline B11 & $\begin{array}{l}\text { Kondisi fisik pada responden baik terdapat organ yang } \\
\text { perlu diperhatikan yaitu kelenjar air susu, sistem syaraf }\end{array}$ & Kelenjar pituitary \\
\hline B12 & $\begin{array}{l}\text { Kondisi fisik responden terdapat permasalahan pada } \\
\text { beberapa organ kurang sehat yaitu rektum, sakrum, usus } \\
\text { buntu, rahang dan gigi }\end{array}$ & Kelenjar air susu \\
\hline B13 & $\begin{array}{l}\text { Kondisi fisik responden dalam kondisi kurang sehat } \\
\text { terlihat pada organ rahang dan gigi, sistem syaraf, sistem } \\
\text { kekebalan tubuh, organ limpa }\end{array}$ & $\begin{array}{l}\text { Sistem } \\
\text { tubuh }\end{array}$ \\
\hline B14 & $\begin{array}{l}\text { Kondisi fisik responden kurang baik pada organ rektum, } \\
\text { sakrum, sistem urine, kelenjar air susu, liver, tenggorok, } \\
\text { kelenjar tiroid }\end{array}$ & Tulang belakang \\
\hline B15 & $\begin{array}{l}\text { Kondisi fisik responden secara umum kelelahan, ada } \\
\text { beberapa bagian dengan kondisi fisik kurang sehat seperti } \\
\text { servik, paru-paru }\end{array}$ & $\begin{array}{l}\text { Sakrum, liver, } \\
\text { tulang belakang }\end{array}$ \\
\hline B17 & $\begin{array}{l}\text { Kondisi fisik responden kurang sehat, terlihat pada organ } \\
\text { bagian kiri yaitu organ rektum dan liver yang lemah }\end{array}$ & Jantung kanan \\
\hline
\end{tabular}

Analisa hasil pengukuran kesehatan fisik responden pre testdan post test antara kelompok kontrol dan kelompok intervensi. Dari tabel 4 keluhan fisik responden pada kelompok kontrol tidak berubah dan beberapa responden mengalami kelelahan fisik. Pada tabel 5 hampir semua responden kelompok intervensi dalam kondisi kesehatan optimal. 
Tabel. 6

Pengukuran Keseimbangan Organ (Organs Energy) pada Kelompok Kontrol dan Pranic Healing

\begin{tabular}{cccccccccc}
\hline Kelompok & Klasifikasi & \multicolumn{2}{c}{ Pre Test } & \multicolumn{2}{c}{ Post Test 1 } & \multicolumn{2}{c}{ Post Test 2 } & \multicolumn{2}{c}{ Post Test 3 } \\
& Tekanan Emosi & F & $\%$ & F & $\%$ & F & $\%$ & F & $\%$ \\
\hline \multirow{4}{*}{ Kontrol } & Very Low & - & - & - & - & 1 & 7,1 & - & - \\
& Low & 3 & 21,4 & 2 & 14,3 & 6 & 42,9 & 8 & 57,1 \\
& Normal & 11 & 78,6 & 12 & 85,7 & 7 & 50 & 6 & 42,9 \\
& Increased & - & - & - & - & - & - & - & - \\
& High & - & - & - & - & - & - & - & - \\
& Jumlah & 14 & 100 & 14 & 100 & 14 & 100 & 14 & 100 \\
& Very Low & - & - & - & - & - & - & - & - \\
Pranic & Low & 1 & 7,3 & 3 & 21,4 & 5 & 35,7 & 9 & 64,3 \\
Healing & Normal & 13 & 92,9 & 22 & 78,6 & 9 & 64,3 & 5 & 35,7 \\
& Increased & - & - & - & - & - & - & - & - \\
& High & - & - & - & - & - & - & - & - \\
& Jumlah & 14 & 100 & 14 & 100 & 14 & 100 & 14 & 100 \\
\hline
\end{tabular}

Analisa pengukuran energi organ (organs energy) yang dibagi menjadi 5 skala yakni sebagai berikut sangat rendah (0-2), rendah (2-4), normal (4-6), increased (6-8) dan high (8-10). Hasil energi organ (organ energy) pada kelompok kontrol dan pranic healing disajikan pada tabel 6 .

Berdasarkan tabel 6 hasil pre test responden kelompok kontrol 3 orang energi organ pada skala low dan 11 orang pada kondisi normal, untuk kelompok Pranic Healing 1 orang kondisi low dan 13 orang kondisi normal. Pada post test 1 kelompok kontrol ada 12 orang pada kondisi normal dan pada kelompok pranic healing 11 orang pada kondisi normal.

Hasil pada posttest 2 pada kelompok kontrol terdapat 1 orang pada kondisi energi very low, 6 orang kondisi low dan 7 orang normal, kelompok pranic healing 5 orang pada kondisi low dan 9 orang pada kondisi normal. Post test 3 di kedua kelompok sama sama ada kenaikan jumlah responden yang kondisi energinya low, kelompok kontrol post test 2 jumlahnya 6 orang naik menjadi 8 orang pada post test 3 , sedangkan pada kelompok pranic healing yang pada post test 2 jumlahnya 5 orang bertambah menjadi 9 orang.

Analisa pengukuran nilai mean, standar deviasi, mean rank pada kelompok responden pretest, post test 1, post test 2, post test 3 energi organ (organs energy) disajikan pada tabel 6.

Tabel. 7

Pengukuran Nilai Mean, Standar Deviasi, Mean Rank pada Kelompok Responden Pretest, Post Test 1, Post Test 2, Post Test 3 Energi Organ (Organs Energy)

\begin{tabular}{cllcc}
\hline Kelompok & Test & Mean & Standar Deviasi & P Value \\
\hline \multirow{3}{*}{ Kontrol } & Pre Test & 4,833 & 0,215 & \\
& Post Test 1 & 4,751 & 0,171 & $0,001^{*}$ \\
& Post Test 2 & 4,009 & 0,267 & \\
& Post Test 3 & 3,774 & 0,227 & \\
\hline \multirow{5}{*}{ Pranic Healing } & Pre Test & 4,569 & 0,121 & $0,002^{*}$ \\
& Post Test 1 & 4,576 & 0,172 & \\
& Post Test 2 & 4,094 & 0,21 & \\
& Post Test 3 & 3,899 & 0,89 & \\
\hline
\end{tabular}

Keterangan: *= Uji Repeated Anova 
Untuk nilai mean kelompok pranic healing pre test sampai post test 3 mengalami penurunan dari nilai 4,569 menjadi 3,899 dan ada perubahan pada kelompok pranic healingdengan nilai $\mathrm{p}=0,002<\mathrm{p}=0,05$.

Analisa uji beda energi organ pada setiap nilai pretest, post test 1, post test 2, post test 3 pada kelompok kontrol dan kelompok pranic healing disajikan pada tabel 8 .

Tabel. 8

Analisa Uji Beda Energi Organ pada Setiap Nilai Pretest, Post Test 1, Post Test 2, Post Test 3 pada Kelompok Kontrol dan Kelompok Pranic Healing

\begin{tabular}{ccc}
\hline Kelompok & Test & P Value \\
\hline \multirow{3}{*}{ Kontrol } & Pre Test-Post Test 1 & $0,67^{* *}$ \\
& Pre Test-Post Test 2 & $0,004^{* *}$ \\
& Pre Test-Post Test 3 & $0,001^{* *}$ \\
\hline \multirow{3}{*}{ Pranic Healing } & Pre Test-Post Test 1 & $0,49^{*}$ \\
& Pre Test-Post Test 2 & $0,013^{*}$ \\
& Pre Test-Post Test 3 & $0,001^{*}$ \\
\hline
\end{tabular}

Keterangan: * Uji Wilcoxon, ** Uji Paired T Test

Berdasarkan uji Paired T Test pada tabel 8 untuk kelompok kontrol tidak terdapat perbedaan nilai energi organ antara pre test dengan post test 1 adalah $0,67>\mathrm{p} 0,05$, terdapat perbedaan nilai $\mathrm{p}$ pre test dengan post test 2 adalah $0,004<\mathrm{p} 0,05$, dan nilai $\mathrm{p}$ pre test dengan post test 3 adalah 0,001 < p 0,05. Berdasarkan uji Wilcoxon Sign Rank pada tabel 4.14 untuk kelompok pranic healingterdapat perbedaan nilai energi organ pada pre test dengan post test 2 nilai $\mathrm{p} 0,013<\mathrm{p}=0,05$ dan pre test dengan post test 3 nilai $\mathrm{p}=0,001<\mathrm{p} 0,05$, tidak ada perbedaan antara pre test dengan post test 1 nilai $\mathrm{p}=0,49>\mathrm{p} 0,05$.

Perbedaan energi organ (organ energy) antara kelompok kontrol dan kelompok pranic healing sebelum dan sesudah terapi disajikan pada tabel 9.

Tabel. 9

Analisa Nilai Energi Organ

\begin{tabular}{ccc}
\hline Variabel & Test & P Value \\
\hline & Pre Test & 0,297 \\
Energi Organ & Post Test 1 & 0,477 \\
& Post Test 2 & 0,803 \\
& Post Test 3 & 0,617 \\
\hline
\end{tabular}

Keterangan: * Uji Independent T Test

Nilai $\mathrm{p}$ value dari variabel energi organ hasil uji independent $T$ Test antara kelompok kontrol dan kelompok pranic healing, pre test $\mathrm{p}=0,297>0,05$, post test 1 $\mathrm{p}=0,477>0,05$, post test $2 \mathrm{p}=0,803>0,05$, post test $3 \mathrm{p}=0,617<0,05$ sehingga tidak terdapat perbedaan variabel energi organ antara kelompok kontrol dan kelompok pranic healing pada pre test sampai dengan post test 3. 


\section{PEMBAHASAN}

Berdasarkan hasil penelitian yang telah dilakukan, menunjukkan perubahan hasil yang cukup signifikan. Dari hasil uji repead anova untuk variabel energi organ pada kelompok kontrol dan kelompok pranic healing terjadi perubahan yakni dengan menunjukkan dari keduanya mengalami perubahan dengan nilai $p$ value kelompok kontrol $\mathrm{p}=0,002<\mathrm{P}=0,05$ dan kelompok pranic healing $p$ value $=0,002<\mathrm{p}=0,05$. Perubahan tersebut terjadi pada kasus yang sama. Perubahan menunjukkan disebabkan karena kemampuan adaptasi yang baik dari ibu hamil trimester III atas kemampuan tubuh fisik yang terjadi pada masa kehamilan.

Permasalahan kesehatan fisik dapat berupa gangguan akibat rasa kurang nyaman pada area sakrum berupa nyeri dan sakit terjadi pada sebagian besar wanita hamil mulai trimester kesatu dan meningkat sampai trimester ketiga, keluhan rasa sakit di area sakrum merupakan masalah penting selama kehamilan (Manuela Filipec, 2013). Kondisi tersebut secara fisiologis terjadi pada masa kehamilan karena tubuh yang memerlukan adaptasi akibat perubahan hormonal pada kehamilan. Hasil dari penelitian selaras dengan hasil dari penelitian yang telah dilakukan oleh peneliti dimana $35,7 \%$ responden mengalami keluhan fisik pada area sakrum (Manuela Filipec, 2013).

Hal ini diperkuat dengan penelitian Casagrande di Journal of the American Academy of Orthopaedic tahun 2015 disebutkan bahwa angka kejadian nyeri area lumbal pelvic pada ibu hamil sampai dengan usia kehamilan 36 minggu adalah sebesar 62\%. (Casagrande, Danielle MD et al, 2015) Pada hasil penelitan terdapat 28,5\% responden mengalami keluhan di area anus dan rektum dengan bervariasi masalah gangguan yang muncul, seperti konstipasi dan haemorrhoid. Penelitian yang dilakukan oleh Adeir Moreira Rocha Junior menyebutkan bahwa 68\% wanita hamil mengalami gangguan rasa nyaman di area anus terutama masalah konstipasi dan haemorrhoid. Konstipasi adalah faktor resiko terpenting sehingga upaya pencegahan konstipasi selama kehamilan sangat direkomendasikan. Kecenderungan keluhan tersebut terjadi pada masa kehamilan, pentingnya penanggulangan untuk dapat mengurangi berbagai keluhan dan proses kehamilan yang lebih nyaman (Adeir Moreira Rocha Junior, Beatriz Juliao Vieira et al, 2007).

Permasalahan yang diakibatkan tubuh fisik tersebut, secara langsung dan tidak langsung menyebabkan kondisi lain yang ditimbulkan pada ibu hamil seperti halnya kecemasan. Kecemasan merupakan permasalah yang biasa terjadi pada ibu hamil, kecemasan yang terjadi dapat meningkat menjadi stres sampai depresi berat, 15,6\% ibu hamil mengalami kecemasan, hasil penelitian tersebut hampir sama dengan hasil pengukuran penelitian 17,8\% ibu hamil mengalami kecemasan (C Rubertsson, 2013).

Apabila kecemasan tersebut tidak dilakukan penanggulangan maka efek yang ditimbulkan akan berdampak dalam waktu jangka panjang. Pranic Healing melalui menerapannya melalui prana energi dapat membantu secara efektif dalam mengurangi efek jangka panjang pada kecemasan. Kecemasan yang terjadi pada masa kehamilan dipengaruhi oleh faktor hormonal, kondisi tersebut akan terus berlanjut pada masa persalinan yang disebabkan akibat terpapar kandungan lithium dan antipsikotik yang menyebabkan hingga masa postpartum hingga setelahnya (Eline M. P. Poels, Lisanne Schijver, 2018).

Melalui pendeteksian alat dengan tingkat akurasi yang tepat dalam menangulangi berbagai permasalahan yang terjadi pada masa kehamilan melalui energi prana dan intervensi penerapan terapi Pranic healing dalam menanggulangi berbagai permasalahan yang ada. Dari hasil penelitian yang telah dilakukan menunjukkan bahwa 
terjadi perubahan yang baik pada kelompok intervensi, perubahan yang terjadi secara signifikan tersebut disebabkan karena adanya proses pengurangan energi dan pembaharuan energi luar yang membantu dalam mengendalikan energi tubuh fisik yang ada dalam tubuh. Maka dapat disimpulkan bahwa terapi pranic healing secara efektif mampu meningkatkan kualitas kesehatan fisik pada primigravida trimester III.

\section{SIMPULAN}

Terdapat peningkatan kesehatan fisik dan energi pada ibu hamil setelah dilakukan intervensi terapi pranic healing pada ibu hamil primigravida trimester III. Dari hasil pre test dan post test didapatkan jumlah keluhan tubuh fisik pada responden kelompok pranic healing berkurang, sedangkan pada kelompok kontrol muncul keluhan tubuh fisik yang baru. Dari hasil tersebut dapat disimpulkan bahwa terapi pranic healing dapat meningkatkan kesehatan tubuh fisik dan tubuh energi ibu hamil.

\section{SARAN}

Berdasarkan hasil penelitian yang telah dilakukan, diharapkan penerapan Pranic Healing dapat dilakukan secara menyeluruh pada setiap tahapan fasilitas kesehatan.

\section{DAFTAR PUSTAKA}

Adeir, M. R. J., Beatriz, J. V., Luis, C. F. Ae, Fernando M. A. (2007). Effects of LowLevel Laser Therapy on the Progress of Wound Healing in Humans: The Contribution of in Vitro and in Vivo Experimental Studies, 6(3)

Bethsaida, J. (2010). Pendidikan Psikologi untuk Bidan: Suatu Teori dan Terapannya. 1, editor. Yogyakarta: Rapha Publishing; $350 \mathrm{p}$

Casagrande., Danielle, M. D. (2015). Low Back Pain and Pelvic Girdle Pain in Pregnancy. Journal of the American Academy of Orthopaedic Surgeons, 23(9), 539-549

Eline, M. P. P. (2018). Long-Term Neurodevelopment Consequences of Intrauterine Exposure to Lithium and Antipsychotics: A Systematic Review and MetaAnalysis. European Child and Adolescent Psychiatry, 27, 1209-1230. doi.org/10.1007/s00787-018-1177-1

Manuela, F. (2013). GDV Analysis of Arterial Hypertension. K.G.Korotkov, editor. Saint Petersburg: Amazon. $9 \mathrm{p}$

Peraturan Menteri Kesehatan Republik Indonesia. (2016). Peraturan Menteri Kesehatan Republik Indonesia No 43 Tahun 2016 tentang Standar Pelayanan Minimal di bidang Kesehatan

Podvornik, N., Velikonja, V. G., \& Praper P. (2015). Depression and Anxiety in Women During Pregnancy in Slovenia/Depresija In Anksioznost Pri Ženskah Med Nosečnostjo V Sloveniji. Slovenian Journal of Public Health, 54(1), 45-50

Rajagopal, R., Jois, S. N., Mallikarjuna, M. S, Anil, K., Shashidhar, H. B. (2017). Amelioration of Mild and Moderate Depression Through Pranic Healing as Adjuvant Therapy: Randomised Double-Blind Controlled Trial. Australas Psychiatry. 1039856217726449

Rubertsson, C. (2013). Energy Fields Electrophotonic Analysis in Humans and Nature. 2nd ed

Sui, M. C. K. (2009). Pranic Psychotherapy. 8 ed. Jakarta: PT Gramedia; Hal 54. November 
Sui, M. C. K. (2010). Keajaiban Penyembuhan Prana: Tuntunan Praktis Penyembuhan Prana: Surya Cahaya, the Institute for Inner Studies Publshing Foundation,Inc.; 2010. $377 \mathrm{p}$

Sui, M. C. K. (2010). Pranic Healing Tingkat Mahir: Advanced Pranic Healing. 12 ed. Surakarta, Indonesia: Yayasan Prana Jawa Bali, Surya Cahaya, the Institute for Inner Studies Publishing Foundation, Inc

Sui, M. C. K. (2010). The Chakras and Their Functions. Metro Manila: The Institute for Inner Studies Publishing Foundation. 212 p 